Kajian Ilmiah Mata Kuliah Umum

Volume 15 Nomor 1, September 2015

Penerbit
Pelindung dan Penasehat
Penanggung Jawab
Pemimpin Umum
Penyunting Ahli
Pemimpin Redaksi
Sekretaris Redaksi
Anggota Redaksi

Sekretariat
: Pusat MKU Universitas Negeri Yogyakarta

: Wakil Rektor I UNY

: Wawan S. Suherman

: Sunarso

: Marzuki

: Rukiyati

: Vita Fitria

: Sri Agustin Sutrisnowati, Amir Syamsudin, Syukri Fathudin Achmad Widdodo,

Benni Setiawan

: Ari Saraswati

Alamat Redaksi/Tata Usaha:
Pusat MKU UNY, Gedung LPPMP Lt.3 Sayap Timur
Kampus Karangmalang Yogyakarta
Email: mku@uny.ac.id, mku.uny@gmail.com, ruki1961@yahoo.com

HUMANIKA Kajian Ilmiah Mata Kuliah Umum menerima kiriman tulisan/artikel yang terkait dengan Mata Kuliah Umum (MKU), yang meliputi Pendidikan Agama, Pendidikan Pancasila, Pendidikan Kewarganegaraan, Ilmu Sosial Dasar, Ilmu Budaya Dasar, Ilmu Alamiah Dasar, dan Pendidikan Kependudukan dan Lingkungan Hidup, dengan ketentuan sebagai berikut:

1. Naskah dapat berupa hasil penelitian atau artikel ilmiah bebas dan belum pernah diterbitkan.

2. Naskah diketik dengan spasi satu setengah (1,5 spasi) dengan jumlah halaman 1015 halaman kuarto, diketik dengan MS Word ukuran font 12 Times New Roman.

3. Naskah memuat komponen: judul ( $<10 \mathrm{kata})$, nama penulis, alamat email, abstrak (100-150 kata), isi karangan (yang memuat pendahuluan, pembahasan, kesimpulan) dan daftar pustaka.

4. Naskah dikirim dalam bentuk print out dan soft copy.

5. Daftar pustaka ditulis secara alfabetis seperti berikut:

- Hidayat, Komaruddin. 2004. Menafsir Kehendak Tuhan. Jakarta: Serambi.

- Bagir, Haidar. 2012. "Syiah dan Kerukunan Umat". Republika. 20 Januari. 


\section{DAFTAR ISI}

Redaksi Humanika ........................................................................... i

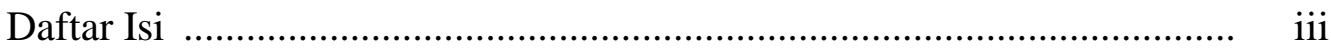

Pengantar Redaksi ...........................................................................

Islam Rahmah dan Wasathiyah

(Paradigma Keberislaman Inklusif, Toleran dan Damai)

Abd. Malik Usman........................................................................... 1-12

The Dialectics of Javanese and Islamic Cultures:

an Introduction to Kuntowijoyo's Thought

Pradana Boy ZTF

Persepsi Masyarakat Kotagede Terhadap Pengunaan Media Komunikasi oleh Organisasi Forum Joglo untuk Peletarian Budaya di Kotagede

Yogyakarta

Choirul Fajri

Implikasi Budaya Organisasi Terhadap Pola Perilaku Komunikasi

Kelompok Tani Sumber Rejeki

Mariana Ulfah dan Siti Chotijah

Etika Sosial dalam Kerukunan Umat Beragama

(Studi Kasus di Desa Kotesan Kecamatan Prambanan Kabupaten Klaten

Jawa Tengah)

Andy Dermawan dan Zunly Nadia

Model Komunikasi "Wom" Sebagai Strategi Pemasaran Efektif

Dani Fadillah

Mencari Model Pendidikan Karakter

Suparlan 


\title{
MENCARI MODEL PENDIDIKAN KARAKTER
}

\author{
Suparlan, M.Pd.I \\ suparlan.ppwi@gmail.com \\ Universitas Negeri Yogyakarta
}

\begin{abstract}
Abstrak
Pendidikan karakter merupakan keniscayaan, karena terbukti mampu mengantarkan kesuksesan akademik dan kehidupan, mampu membantu mempersiapkan anak menghadapi tantangan hidu, mampu membantu mendorong tingkah laku baik, memudahkan guru dalam proses pembelajaran. Pendidikan karakter menjadi mendesak untuk diterapkan disemua aspek pendidikan karena melihat realitas manusia yang sudah semakin jauh dari nilai - nilai kebenaran.

Pendidikan karakter adalah ditujukan untuk membangun nilai, sikap dan prilaku anak didik secara konsisten, sehingga prilaku anak didik senantiasa dengan ikhlas istiqomah dengan prilaku baik dalam situasi dan kondisi apapun. Model pendidikan karakter yang dikembangkan adalah model pendidikan keterpaduan yang mengoptimalkan seluruh komponen keluarga baik keluarga, sekolah, dan masyarakat, dan penendiikan yang mengintegrasikan pengoptimalan potensi hati, akal, jiwa, fisik anak.
\end{abstract}

\section{A. PENDAHULUAN}

Indonesia memerlukan sumberdaya manusia yang tidak hanya memiiliki keahlian dalam ilmun pengetahuan, melainkan sekaligus memiliki karakter yang luhur, sebagai pendukung utama dalam pembangunan. Dalam memenuhi sumberdaya manusia tersebut, pendidikan memiliki peran yang sangat penting. Pendidikan sesuai dengan UU No 20 Tahun 2003 Tentang Sistem Pendidikan Nasional, bertanggung jawab atas pengembangan SDM berkualitas yakni, pendidikan nasional berfungsi mengembangkan kemampuan dan membentuk karakter serta peradaban bangsa yang bermartabat dalam rangka mencerdaskan kehidupan bangsa. Pendidikan nasional bertujuan mengembangkan potensi peserta didik agar menjadi manusia yang beriman dan bertakwa kepada Tuhan Yang Maha Esa, berakhlak mulia, sehat, berilmu, cakap, kreatif, mandiri, dan menjadi warga negara yang demokratis serta bertanggung jawab.

Peran luhur pendidikan dalam mengembangkan hard skill (untuk mengarahkan anak bangsa memiliki kemampuan menguasai ilmu pengetahuan, teknologi, dan ketrampilan teknis yang sesuai dengan pengembangan bidang ilmu), dalam realitasnya sering tidak diberengi dengan pengembangan sof skill, (keterampilan intra-personal dan inter-personal yang dapat mengembangkan dan memaksimalkan kinerja). Akibatnya 
banyak anak bangsa yang telah memiliki kemajuan dan keahlian dalam ilmu pengetahuan dan ketrampilan, mereka masih sering kurang mampu dalam menjalin komunikasi dan kerjasama yang harmonis sebagai sesama warga, warga dengan pemerintah dan negara. Ironisnya lagi mereka yang diberi tanggungjawab atas keahliannya dalam tugas tertentu, justru mereka menjadi sumber dari ketidak harmonisan.

Tanggap terhadap krisis karakter bangsa Pemerintah seperti tertulis dalam Kebijakan Nasional Pembangunan Karakter Bangsa menyatakan (Republik Indonesia. 2010: 1), situasi dan kondisi karakter bangsa yang memprihatinkan, mendorong pemerintah mengambil inisiatif untuk memprioritaskan pembangunan karakter bangsa. Dengan maksud agar setap upaya pembangunan harus selalu diarahkan untuk dapat memberikan dampak yang positif terhadap pengembangan karakter. Dan prioritas pembangunan karakter juga nampak jelas dalam Rancangan Pembangunan Jangka Panjang Th 2005 - 2025 yaitu:

...terwujudnya karakter bangsa yang tangguh, kompetitif, berakhlak mulia,. Dan bermoral berdasarkan Pancasila, yang dicirikan dengan watak dan prilaku manusia dan masyarakat Indonesia yang beragam, beriman dan bertaqwa pada Tuhan YME, berbudi luhur, bertoleran, bergotongroyong, berjiwa patriotik, berkembang dinamis, dan berorientasi iptek, ( UURP No .17. 2007)

Pendidikan mempunya peran yang strategis untuk memainkan peran dalam pembangunan karakter bangsa. Mutu pendidikan karakter tidak boleh ditawar lagi. Dan Kementerian Pendidikan Nasional harus memberikan pethatian serius mengembangkan grand design pendidikan karakter untuk setiap jalur, jenjang, dan jenis satuan pendidikan. Grand design harapanya dapat menjadi rujukan konseptual dan operasional pengembangan, pelaksanaan, dan penilaian pada setiap jalur dan jenjang pendidikan.

\section{B. KENISCAYAAN PENDIDIKAN KARAKTER}

Ajaran Islam menyakini, pembentukan karakter merupakan tujuan yang sangat peting dari semua rangkaian proses pelaksanaan sistem ajaran Islam. Pada hadis yang sangat populer Rasulullah saw bersabda: " $A k u$ diutus hanyalah untuk menyempurnakan keluhuran akhlak". Bahkan beliau berani menjamin bagi siapapun yang mau berusaha meningkatkan akhlaknya akan mendapat imbalan surga sesuai dengan tingkat usahanya. Abu Umamah AlBahli berkata, Rasulullah saw bersabda Aku berani menjamin sebuah rumah di surga bagian bawah bagi orang yang meninggalkan debat kusir walaupun ia benar, sebuah rumah di surga bagian tengah bagi orang yang meninggalkan 
dusta walaupun ia bergurau, dan sebuah rumah di surga bagian atas bagi orang yang selalu baik budipekertinya/ akhlaknya. (Imam Nawawi, 2011: 335). Pendidikan karakter sebagai pilar utama Islam yang diserukan Rasulullah, ribuan tahun kemudian dirumuskan kembali oleh beberapa tokoh pendidikan, bahwa tujuan utama pendidikan adalah pada wilayah pembentukan kepribadian manusia yang utama.

Brooks dan Goble misalnya
seakan menggaungkan kembali
tujuan seperti ini, keduanya
menyatakan bahwa karakter adalah
tujuan yang tak terhindarkan dari
dunia pendidikan (Abdul Majid,
2012: 30). Ratna Megawangi (2014:
24) dengan mengutip pendapat Lickona, menjelaskan pendidikan moral harus dilakukan sejak usia dini, karena mendidik moral pada usia dini ibaratnya dari awal anak telah diisi dengan kasih sayang dan kebaikan sehingga ketika dewasa anak hanya berisi kesucian dan kebajikan dalam perjalanan hidupnya.

Pentingnya pendidikan karakter, secara logika dapat dibenarkan karena merupakan salah satu faktor yang akan mengantarkan kehidupan individu, masyarakat dang bangsa mencapai kejayaan. Mc. Graw Hill sedikitnya mencatat ada empat alasan mengapa karakter perlu dididikkan. Alasan pertama adalah karena terbukti pendidikan karakter mampu mengantarkan anak meraih kedua kesuksesan baik pada aspek akademik dan kehidupan. Kedua pendidikan karakter mampu membantu mempersiapkan anak dapat menghadapi berbagai tantangan kehidupan. Ketiga, pendidikan karakter mampu membantu mendorong tingkah laku pro-sosial dan menahan sikap negatif dan tingkah laku anti sosial anak. Keempat, pendidikan karakter memudahkan guru dalam proses pembelajaran dan membuat proses pembelajaran menjadi lebih efektif (Mc. Graw Hill, 2007: 2-4) .

Pendidikan

karakter

menjadi hal yang mendesak untuk dilakukan, terutama melihat realitas karakter manusia yang sudah semakin jauh dari nilai-nilai kebenaran. Abdul Qadir Abu Faris (2005: 11-12) melalui perenungan terhadap fenomena umat Islam menyampaikan jeritan hatinya. Beliau prihatin atas fenomena para tokoh pergerakan Islam yang sudah dijangkiti sifat sombong, riya, angkuh, dan menonjolkan citra diri (ketaqwaan, kebaikan) untuk meraih kepentingan duniawi. Fenomena ketika umat islam yang seharusnya sedang berada dalam kesucian (majlis dzikir, majlis ta'ziyah, dan lain-lain), malah tertawa-tawa tidak peka dengan melihat tujuan hidup dirinya dan tidak peka melihat penderitaan orang lain. Umat Islam yang begitu boros harta untuk kepentingan pribadi, kikir untuk kepentingan sosial kemasyarakatan dan agama.

Keprihatinan terhadap moral bangsa juga disampaikan oleh Dharma Kesuma dkk (2011) yakni 
merosotnya moral remaja (maraknya sek bebas, narkoba, tawuran, peredaran foto dan video porno), pengangguran terdidik yang sangat menghawatirkan, rusaknya moral bangsa (korupsi, asusila, kejahatan, tindakan kriminal) yang merajalela, berbagai bencana yang bertubi-tubi menimpa bangsa diduga akibat azab atau kebodohan bangsa, kemiskinan mencapai 40 juta dan terus bertambah, daya kompetitif bangsa yang rendah sehingga tergantikan produk luar, dan adanya inefisiensi pembiyaan pendidikan.

Penjelasan di atas sudah semestinya menggugah para pendidik dan orang tua agar pendidikan karakter dilaksanakan dengan serius. Pendidikan karakter seharusnya dilakukan secara komprehensif, mengoptimalkan berbagai faktor pembentukan karakter baik secara internal dan eksternal, teori dan aplikasi paedagogis, keluarga dan masyarakat. Pendidikan karakter merupakan tanggung jawab semua pendidik, orang tua dan masyarakat. Terabaikannya pendidikan karakter atau tidak seriusnya menjalankan tugas mulia ini, akan berdampak pada kemorosotan moral yang lebih kronis.

\section{MAKNA PENDIDIKAN KARAKTER}

Dalam sejarah perundang undangan di Indonesia yang pernah berlaku (UU 4/1950, 12/154, 2/89), sebenarnya pendidikan karakter dengan rumusan yang berbeda secara substantif semua undangundang telah memuatnya sebagai salah satu bagian dari tujuan pendidikan nasional (Winataputra, 2010: 6). Dan pada UU SISDIKNAS No. 20 Tahun 2003 Pasal 3, komitmen pendidikan nasional terhadap pendidikan karakter dengan mempertegas dalam tujuan pendidikan nasional yakni: Pendidikan Nasional berfungsi mengembangnkan kemampuan dan membentuk watak serta peradaban bangsa yang bermartabat dalam rangka mencerdaskan kehidupan bangsa (UU SISDIKNAS No. 20 Tahun 2003). Pembentukan watak berarti adalah mengembangkan karakter yang sejalan dengan jiwa dan semangat kebangsaan Indonesia, dan bahkan lebih lanjut tujuan pendidikan nasional dicermati setiap elemennya sangan terkait dengan pembentukan karakter.

Pendidikan karakter sacara historis juga telah dicanangkan oleh Ki Hajar Dewantara, belia menyatakan, “... Pendidikan merupakan daya upaya untuk memajujakan bertumbuhnya budi pekerti (kekuatan batin, karakter ) pikiran (intelect), dan tubuh anak. Bagian-bagian itu tidak boleh dipisahkan agar kita dapat memajukan kesempurnaan hidup anak-anak kita" (Winataputra, 2010: 7). Hal ini sejalan dengan rumusan tujuan pendidikan dalam SISDIKNAS, yang sangat jelas menyiratkan bahwa melalui pendidikan hendak diwujudkan 
peserta didik yang secara utuh memiliki berbagai kecerdasan, baik kecerdasan spiritual, emosional, sosial, intelektual maupun kecerdasan kinestetika. Dan misi pendidikan ini sungguh sangat mulia bagi peserta didik.

\section{Karakter dari kata} character yang berarti to engrave yang dapat dimaknai dengan mengukir, melukis, memahatkan atau menggoreskan. Simon Phillips menjelaskan karakter adalah kumpulan tata nilai yang mengarah pada satu sistem, yang kemudian sisitem itu menjadi landasan dalam pemikiran, sikap dan prilaku yang ditampilkan (Mu'in, 2011: 160). Menurut Thomas Lickona (1991: 51), karakter adalah "a reliable inner disposition to respond to situations in a morally good way". Yakni merupakan disposisi batiniah yang sudah handal yang digunakan untuk menanggapi situasi dengan cara yang baik secara moral.

Karakter memiliki ciri-ciri: karekter adalah siapakah kamu dan apakah kamu pada saat orang lain sedang melihatmu; Karakter adalah hasil dari nilai-nilai dan keyakinankeyakinan; Karakter adalah sebuah kebiasaan yang menjadi sifat alamiah kedua; Karakter bukanlah reputasi atau apa yang dipikirkan orang lain terhadapmu; dan Karakter adalah bukanlah seberapa baik kamu dari pada orang lain.

Karakter dengan demikian dapat diartikan sebagai sistem nilai tertentu yang diyakini dan terpatri dalam batin seseorang, yang secara totalitas digunakan untuk merespon situasi baik ketika berfikir, bersikap, dan berprilaku dengan cara yang baik secara moral. Karakter juga merujuk pada kekhasan prilaku seseorang, apabila seseorang berprilaku curang, pembohong, kejam, rakus, dan ingkar janji, maka orang tersebut telah memanifestasikan prilaku buruk. Seseorang baru akan dikatakan berkarakter baik apabila dalam kehidupannya merealisasikan sikap dan prilaku, rajin, jujur, adil, dermawan, simpatik dan sejenisnya.

Karakter sebagai totalitas nilai yang mengarahkan manusia dalam menjalani tugas kehidupan, merupakan hasil dari proses panjang manusia dalam pergumulan kehidupan. Pengalaman dalam pergaulan hidup dengan masyarakat dan lingkungan akan memberikan pemahaman terhadap tatanan dan situasai kehidupan masyarakat. Tatanan kehidupan masyarakat merupakan aturan, yang siapapun hidup ditengahnya ada keharusan menyesuaikannya baik, nilai, sikap, dan prilaku.

Karakter dapat dimaknai
sebagai kehidupan berprilaku
baik/penuh kebajikan, yakni
berprilaku baik terhadap pihak lain
(Tuhan, Manusia, alam semesta) dan
terhadap didri sendiri. Secara
subtantif karakter terdidri atas tiga
unjuk prilaku yang saling berkaitan,
yakni moral knowing, moral feeling,
dan moral behavior (Winataputra,
2010: 7). Dengan demikian dapat
dimaknai karakter yang baik adalah

Karakter dapat dimaknai sebagai kehidupan berprilaku baik/penuh kebajikan, yakni berprilaku baik terhadap pihak lain (Tuhan, Manusia, alam semesta) dan terhadap didri sendiri. Secara subtantif karakter terdidri atas tiga unjuk prilaku yang saling berkaitan, yakni moral knowing, moral feeling, dan moral behavior (Winataputra, dimaknai karakter yang baik adalah 
mengetahui kebaikan, mau berbuat baik, dan nyata berprilaku baik. Keutuhan karakter tersebut secara koheren adalah merupakan pancaran dari berlangsungnya olah hati, olah pikir, olah jiwa/ karsa olah raga.

Pendidikan karakter dengan demikian dapat dimaknai sebagai pendidikan nilai, pendidikan budi pekerti, pendidikan moral, pendidikan watak, yang bertujuan mengembangkan kemampuan peresta didikan untuk memberikan keputusan baik-buruk, memelihara apa yang baik, dan mewujudkan kebaikan itu dalam kehidupan sehari hari dengan sepenuh hati. Menurut Foerster ada empat ciri dasar dalam pendidikan karakter. Pertama, keteraturan interior di mana setiap tindakan diukur berdasar hierarki nilai. Nilai menjadi pedoman normatif setiap tindakan. .Kedua, koherensi yang memberi keberanian, membuat seseorang teguh pada prinsip, tidak mudah terombangambing pada situasi baru atau takut risiko. Koherensi merupakan dasar yang membangun rasa percaya satu sama lain. Tidak adanya koherensi meruntuhkan kredibilitas seseorang.

Ketiga, otonomi disini seseorang menginternalisasikan aturan dari luar sampai menjadi nilai-nilai bagi pribadi. Ini dapat dilihat lewat penilaian atas keputusan pribadi tanpa terpengaruh atau desakan pihak lain. Keempat, keteguhan dan kesetiaan. Keteguhan merupakan daya tahan seseorang guna mengingini apa yang dipandang baik. Dan kesetiaan merupakan dasar bagi penghormatan atas komitmen yang dipilih (Winataputra, 2010: 10).

Nilai nilai karakter yang seharusnya dididikkan ,menurut Thomas Lickona ada tujuh unsur nilai karakter yaitu: ketulusan hati atau kejujuran (honesty), belas kasih (compassion), kegagahberanian (courage), kasih sayang (kindness), kontrol diri (self-control), kerja sama (cooperation), kerja keras (deligence or hard work)

Dalam naskah akademik Pengembangan Pendidikan Budaya dan Karakter Bangsa, Kementerian Pendidikan Nasional telah merumuskan lebih banyak nilai-nilai karakter, ada 18 nilai yang akan dikembangkan atau ditanamkan kepada anak-anak dan generasi muda bangsa Indonesia. Nilai-nilai karakter tersebut adalah: Religius, jujur, toleransi, disiplin, kerja keras, kreatif, mandiri, demokratis, resa ingin tahu, semangat kebangsaan, cinta tanah air, penghargai prestasi,

\section{KEBIJAKAN PENDIDIKAN KARAKTER}

Di tengah kebangkrutan moral bangsa, maraknya tindak kekerasan, inkoherensi politisi atas retorika politik, dan perilaku keseharian, pendidikan karakter menjadi relevan untuk diterapkan. Perlunya kebijakan pendidikan karakter atas dasar argumen akan adanya kebutuhan nyata dan mendesak, 
proses transmisi nilai untuk membentuk peradaban, realitas peran pendidikan yang vital dalam pengembangan watak, Masih adanya kode etik di masyarakat yang sarat konflik nilai, kebutuhan demokrasi pendidikan moral, kenyataan bahwa tidak ada pendidikan yang bisa bebas nilai, persoalan moral adalah salah satu persoalan dalam kehidupan, dan adanya landasan yang kuat dan dukungan yang luas terhadap pendidikan karakter.

Disampinh itu secara psikologis dan sosial pentingnya pendidikan karakter adalah, karena dengan pendidikan ini akan dapat mengoptimalkan peserta didik dalam mengintegrasikan seluruh potensi individu (kognitif, afektif, konatif, dan psikomotor) dalam konteks interaksi sosiokultural (keluarga, masyarakat) yang akan berlangsung dalam tugas kehidupan mereka.

Dalam sarasehan Nasional Pendidikan Budaya dan Karakter Bangsa tanggal 14 Januari 2010, disepakati tentang urgensi pendidikan karakter sebagai berikut: Pendidikan budaya dan karakter merupakan bagian yang integral yang tak terpisahkan dari pendidikan nasional secara utuh: Pendidikan budaya dan karakter bangsa harus dikembangkan secara komprehensif sebagai proses pembudayaan. Oleh karena itu, pendidikan dan kebudayaan secara kelembagaan perklu diwadahi secara utuh.

\begin{abstract}
Pendidikan budaya dan karakter bangsa merupakan tanggung jawab bersama antara pemerintah, masyarakat, sekolah, dan orang tua. Oleh karena itu, pelaksanaan pendidikan budaya dan karakter harus melibatkan nkeempat unsur tersebut: Dalam rangka merevitalisasi pendidikan dan budaya karakter bangsa diperlukan gerakan nasional guna menggugah semangat kebersamaan dalam pelaksanaan di lapanmgan.
\end{abstract}

Kementrian pendidikan Nasional dalam upaya mewujudkan pendiikan nasional menyusun desains induk pendidikan karakter. Secara garis besar keseluruhan desain induknya adalah sebagai berikut: Secara makro pengembangan karakter dapat dibagi dalam tiga tahap, yakni perencanaan, pelaksanaan, dan evaluasi hasil. Pada tahap perencanaan dikembangkan perangkat karakter yang digali, dikristalisasi, dan dirumuskan dengan berbagai sumber 1. Filosofis (agama, Pancasila, UUD 45, UU SISDIKNAS). 2. Teoritis ( teori otak, psikologi, pendidikan, nilai dan moral, dan sosio kultural). 3. Empiris, pengalaman dan praktek terbaik dari tokoh, satuan pendidikan unggulan, pesantren, dan kelompok kultural:

Pada tahap implementasi, dikembangkan pengalaman belajar dan proses pembelajaran yang bermuara pada pembentukan karakter dalam diri peserta didik. 
Prosesnya dilaksanakan melalui proses pembudayaan dan pemberdayaan di Tri Pusat Pendidikan dengan pendekatan intervensi dan habituasi:

Dalam kontek makro kehidupan berbangsa dan bernegara Indonesia pendidikan karakter merupakan komitmen seluruh sektor kehidupan, bukan hanya sektor pendidikan nasional. Keterlibatan aktif dari sektor-sektor pemerintah lainnya, khususnya sektor keagamaan, hukum dan hak azazi manusia, serta pemuda dan olahraga:

Pada tahap evaluasi hasil, dilakukan asesmen program untuk pebaikan berkelanjutan yang sengaja dirancang dan dilaksanakan untuk mendeteksi aktualisasi karakter dalam diri peserta didik sebagai indikator bahwa proses pembudayaan dan pemberdayaan karakter itu berhasil dengan baik (Kemendiknas, 2010: 11-12).

Dan pada tataran mikro, pendidkan karakter ditata oleh kemandiran pendidikan sebagai berikut: Secara mikro pengembangan nilai/karakter dapat dibagi dalam empat pilar, yakni kegiatan belajar mengajar di kelas, kegiatan keseharian dalam bentuk budaya satuanpendidikan, kegiatan ko-kurikuler dan/atau ekstra kurikuler, serta kegiatan keseharian di rumah, dan dalam masyarakat:
Dalam kegiatan belajar mengajar di kelas pengembangan nilai/karakter dilaksanakan dengan menggunakan pendekatan terintegrasi dalam semua mata pelajaran (embeded approach). Khusus, untuk pendidikanAgama dan Pendidikan Kewarganegaraan, karena misinya adalah pengembangan nilai dan sikap, maka pengembangannya harus menjadi fokus utama yanh menggunakan berbagai strategi/metode pendidikan nilai. Untuk Pendidikan Agama dan Pendidikan Kewarganegaraan dikembangkan sebagai dampak pembelajaran dan dampak pengiring, sedang pada mata pelajaran lain diarahkan pada dampak pengiringnya:

Dalam lingkungan satuan pendidikan dikondisikan agar lingkungan fisik dan sosio-kultural satuan pendidikan memungkinkan para peserta didik bersama dengan warga kesatuan pendidikkan terbiasa membangun kegiatan keseharian yang mencerminkan perwujudan nilai/karakter:

Dalam kegiatan ko-kurikuler dan ekstra kurikuler dikembangkan proses pembiasaan dan penguatan dalam rangka pembentukan karakter: Di lingkungan keluarga dan masyarakat, diupayakan agar terjadi proses penguatan dari orang tua, tokoh masyarakat terhadap prilaku mulia yang dikembangkan di satuan pendidikan, sehingga menjadi kegiatan keseharian dirumah dan 
masyarakat masing-masing

(Kendiknas: 13).

\section{E. MODEL PENDIDIKAN KARAKTER}

Selama ini, pendidikan terutama dalam lingkungan keluarga belum memberikan kontribusi berarti dalam mendukung pencapaian kompetensi dan pembentukan karakter peserta didik. Kesibukan dan aktivitas kerja orang tua yang relatif tinggi, kurangnya pemahaman orang tua dalam mendidik anak di lingkungan keluarga, pengaruh pergaulan di lingkungan sekitar, dan pengaruh media elektronik ditengarai bisa berpengaruh negatif terhadap perkembangan dan pencapaian hasil belajar peserta didik. Salah satu alternatif untuk mengatasi permasalahan tersebut adalah melalui pendidikan karakter terpadu, yaitu memadukan dan mengoptimalkan kegiatan pendidikan informal lingkungan keluarga dengan pendidikan formal di sekolah. Dalam hal ini, waktu belajar peserta didik di sekolah perlu dioptimalkan agar peningkatan mutu hasil belajar dapat dicapai, terutama dalam pembentukan karakter peserta didik .

Memperhatikan kondisi di atas dan menyimak desain mikro pendidikan karakter yang dirumuskan oleh Kementrian Pendidikan Nasional, maka model pendidikan yang sesuai adalah model pendidikan dengan pendidikan komprehensif. Pendekatan komprehensif yang dimaksud adalah mencakup berbagai aspek.

Pertama, isi pendidikannya harus komprehensif, meliputi semua permasalahan yang berkaitan dengan pilihan nilai yang bersifat pribadi sampai pada nilai yang bersifat umum. Kedua, metodenya harus komprehesif. Termasuk didalamnya inkulkasi (penanaman) nilai, pembverian teladan, fasilitasi pembuatan keputusan moral yang bertanggung jawab, dan pengembangan ketrampilan hidup (soft skill). Ketiga, Pendidikan karakter hendaknya terjadi dalam keseluruhan proses pendidikan dilingkungan kelas, kegiatan ekstrakurikuler, dalam proses bimbingan dan dalam semua kegiatan. Keempat, pendidikan karakter hendaknya terjadi dalam masyarakat, keluarga, lembaga keagamaan, penegak hukum, polisi, organisasi kemasyarakatan (Darmiyati Zuhdi, 2010: 2).

Pendidikan karakter, dapat diintegrasikan dalam pembelajaran pada setiap mata pelajaran. Materi pembelajaran yang berkaitan dengan norma atau nilai-nilai pada setiap mata pelajaran perlu dikembangkan, dieksplisitkan, dikaitkan dengan konteks kehidupan sehari-hari. Dengan demikian, pembelajaran nilai-nilai karakter tidak hanya pada tataran kognitif, tetapi menyentuh pada internalisasi, dan pengamalan nyata 
dalam kehidupan peserta didik seharihari di masyarakat.

Kegiatan ekstra kurikuler yang selama ini diselenggarakan sekolah merupakan salah satu media yang potensial untuk pembinaan karakter dan peningkatan mutu akademik peserta didik. Kegiatan Ekstra Kurikuler merupakan kegiatan pendidikan di luar mata pelajaran untuk membantu pengembangan peserta didik sesuai dengan kebutuhan, potensi, bakat, dan minat mereka melalui kegiatan yang secara khusus diselenggarakan oleh pendidik dan atau tenaga kependidikan yang berkemampuan dan berkewenangan di sekolah. Melalui kegiatan ekstra kurikuler diharapkan dapat mengembangkan kemampuan dan rasa tanggung jawab sosial, serta potensi dan prestasi peserta didik.

Pendidikan karakter, menurut Ajat Sudrajat dapat terbentuk dengan baik, jika proses pembelajaran di kelas didukung oleh keteladanan, peraturan dan pembiasaaan. Keterpaduan proses yang diharapkan saling melengkapi dan saling mendukung terbentuknya karaktar minimal melibatkan empat hal: Yaitu, Teaching sebagai proses pembelajaran yang berlangsung di kelas. Modelling, sebagai penguat nilai yang dipelajari di kelas dengan menyuguhkan teladan-teladan nilai yang dapat dilihat dan ditirukan oleh peserta didik. Reinforecing, sebagai upaya untuk menegakkan nilai yang baik dan sekaligus sebagai pengkondisian pada kedisiplinan mentaati nilai luhur. Habituating, pembiasaan nilai oleh pribadi peserta didik untuk mengaplikasikan dan berperilaku baik sesuai dengan nilanilai yang dipelajarinya.

Pendidikan karakter menurut Ary Ginanjar Agustian, adalah berbasis keyakinan dan nilai-nilai yang harus dibawa menuju kerealisasi keyakinan dan nilai. Dalam Model ESQ-65 dijelaskan, sinergi antara kecerdasan spiritual sebagai basis nilai utama, kecerdasan emosional sebagai landasan mental, dan kecerdasan intelektual sebagai solusi hal-halk teknis. Model ESQ adalah mekanisme mengelola kecerdasan intelektual, emosional dan spiritual.

Permasalahannya modelmodel pendidikan di atas belum dapat membuat anak didik memiliki kekokohan nilai karakter yang merupakan perwujudan nilai yang tinggi yang menyatukan kemampuan kognitif, afektif dan psikomotor. Proses seperti ini menurut yang harus dilakukan agar nilai yang diyakini benar-benar menjadi haqqul yaqin dan menjadi panduan karakter dan prilaku yang kokoh dan komit. Permasalahan yang sering muncul sering bertolak belakang dengan realitas prilaku seseorang, yang antara nilai sikap dan prilakunya tidak ada kesesuaian.

$$
\text { Pandangan al-Qur'an }
$$

tentang hubungan antara kesadaran nilai dengan sikap dan prilaku sebenarnya lebih menekankan pada postulat konsistensi. Al-Qur'an 
senantiasa dalam ayat keimanan dirangkai dengan amal/prilaku kebaikan, dan demikian juga sebuah amal baru akan dinilai berkualitas kebaikan jika didasari dengan kesadaran nilai dan kesadaran batin (niat) yang sejalan dengan perilaku/amalnya. Namun demikian al-Qur'an melihat kenyataan hidup yang sering dikuasai oleh lingkungan dan situasi tertentu. Pada fakta kehidupan Islam masih membenarkan pada seseorang menampakkan prilaku ketidak islaman yang tidak sejalan dengan kekokohan iman dalam hatinya, ketika dalam kondisi terpaksa dan lemah (Q.S.al-Ahzab (33): 5 ).

Solusi model pendidikan karakter konsistensi, prosesnya harusnya mengutamakan dahulu pendidikan hati. Hamka menjelaskan bahwa datangnya alQur'an pada orang yang hatinya sakit, tidak akan membuat sembuh penyakitnya, malah membuat hati semakin sakit. Penjelasan ini menggambarkan bahwa sebaik apapun pendidikan yang akan diberikan kepada anak, jika belum memiliki kesiapan hati maka akan tidak memberi manfaat pada perbaikan prilaku. Hati dengan demikian merupakan aspek pendidikan yang paling awal harus diperhatikan.

Tanpa mengabaikan potensi psikologis manusia lainnya, pendidikan hati menempati posisi utama untuk didik. Otak tetap diperlukan karena potensi ini adalah dapat merekam berbagai peristiwa, berfikir, dan mengetahui sesuatu.
Otak adalah sarana yang dapat digunakan untuk membuat hati semakin cerdas, karena fungsi otak bagaikan telinga bagi pendengaran.

Namun tanpa disadari kata

Rusdin S Rauf (2008: 27-28), kemampuan otak yang dahsat itu tidak dapat berfungsi dengan baik tanpa adanya pengendalian dari komponen lain, yakni komponen hati. Hati menjadi pengendali otak didasarkan pada hadis dan pendapat para pakar. Otak mengirim pesan, lalu dalam hati pesan itu diolah. Jika hati jernih ia akan menerjemahkan pesan tersebut dengan jelas dan sebaliknya jika hati kotor maka proses penerjemahan menjadi keruh.

Hati yang terdidik dengan demikian akan mampu mengantarkan pada pembentukan karakter yang baik dan kokoh. Hal ini karena dengan pendidikan hati seseorang menjadi mampu menyerap nilai yang haqqul yaqin. Pendidikan hati juga mengantarkan seseorang agar memiliki kekuatan batin yang diibaratkan bagaikan raja yang akan mengarahkan akal, jiwa dan fisik berprilaku baik. Hati yang sehat akan menjadi filter pemikiran akal, memotivasi jiwa pada dorongan keinginan kebaikan /penghambaan diri pada Allah dan mengendalikan kebutuhan fisik dari kecenderungan negatif. Hati pada akhirnya mengantarkan pada pola pikir sehat, motivasi sebagai hamba Allah, dan dorongan memenuhi kebutuhan duniawi dengan beradab.

Model pendidikan alQur'an, menggambarkan bahwa 
proses pembentukan karakter tidak cukup hanya melalui ranah moral knowing, moral feeling, dan moral behavior, yang empiris pragmatis. Pendiikan karakter hendaknya mengintegrasian ajaran keimanan sebagai pangkal akhlak, dengan tahapan pengetahuan moral (kesadaran moral, pengetahuan moral, penalaran moral, pembuatan putusan moral), tahap perasaan moral (empati, cinta kebaikan, kontrol diri ), dan tindakan moral (keinginan moral, kebiasaan moral).

Pendidikan seperti ini akan memperkokoh ketiga tahapan itu, melalui proses menghubungkan semua tahapan dengan pendidikan hati dan kesadaran akan keagungan/keimanan pada Allah. Proses dimana kebenaran ilmiah dari pengetahuan, perasaan dan tindakan moral disadarkan merupakan bagian integratif dari pengakuan akan kebenaran ilham dan wahyu, melalui perenungan mendalam melalui kekuatan hati yang sehat. Model pendidikan al-Qur'an disamping menambah satu poin karakter berpangkal dari hati yang sehat, juga meluruskan tahapan kognitif, afektif dan psikomotor seperti tergambar di bawah ini :

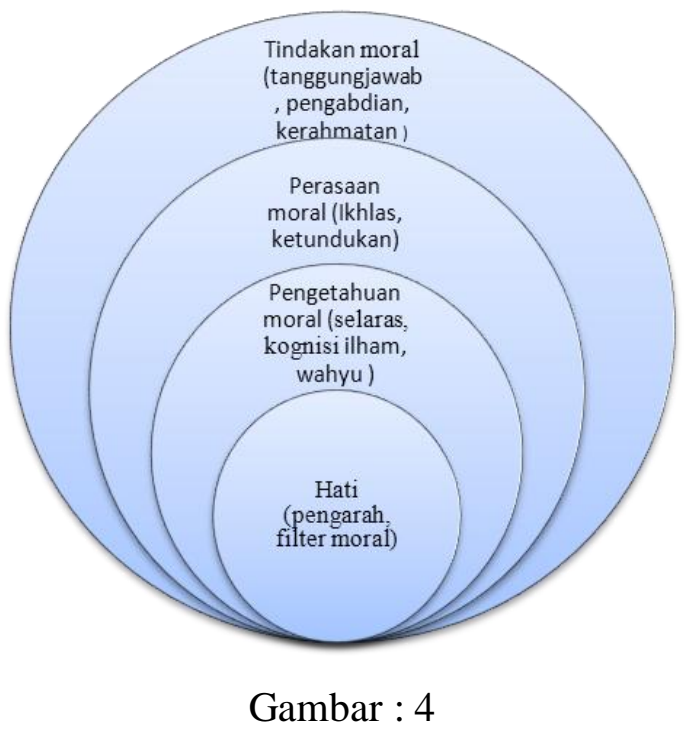

Peran Hati pada Tiga Ranah Karakter

Pada gambar diatas peran hati, kognitif, afektif dan psikomotor tidak dipisahkan. Sesungguhnya keempat tahapan ranah karakter senantiasa terjalin dan bersinggungan, bahkan saling terintegrasi dalam proses tindakan moral. Semua tindakan moral memang kelihatan paling jelas pada tataran praktis, namun demikian tidak ada tindakan moral yang lepas dari afektif, kognitif dan hati. Kualitas tindakan moral justru ditentukan oleh yang tidak nampak, yakni oleh hati yang kemudian dirasionalkan dan diterima secara emosional, dan dinampakkan dalam prilaku.

\section{F. PENUTUP}

Pembahasan pendidikan karakter masih terus dikembangkan, terutama adalah untuk mencari model pendidikan yang tepat dan bisa dijadikan sebagai model. Oleh karena itu pembahasan pada 
makalah ini penulis menyadari masih baru merupakan awal pembahasan, namun demikian ada hal yang penting perlu diperhatikan sebagai kesimpulan, karakter merupakan bagian penting dalam kehidupan manusia, yang telah membentuk jati diri manusia. Proses pembinaan dan pendidikan karakter harus menjadi usaha sadar dan terencana. Pendidikan karakter tanpa perencanaan yang matang dari persiapan, implementasi dan evalusai hasil akan mustahil dapat dicapai dengan baik.

Konsep besar nation and character building Mendiknas haruslah dijabarkan ke dalam program dan kegiatan yang operasional yang jelas dan komprehensif, sehingga dapat dilaksanakan oleh semua pemangku pendidikan, dalam proses pengembangan dan pemupukan karakter, terutama kepada generasi muda. Semua warga dari sebuah keluarga, warga masyarakat, bangsa, dan negara, pendidik beranggung jawab memahami (knowing), mencintai (loving) dan melaksanakan (implementing) nilainilai etika inti (core ethical values) dalam kehidupan untuk membangun berkarakter. Model pendidikan karakter yang dapat dipakai dalam proses pendidikan karakter adalah model pendidikan komprehensif, memadukan hati, akal, jiwa, dan fisik.

\section{DAFTAR PUSTAKA}

Faris, Abdul Qadir Abu. 2005. Mensucikan Jiwa, diterjemahkan oleh Habiburrahman Saeruzi, Jakarta: Gema Insani.

Hill, Mc. Graw. 2007. Introduction to Character Education and Effektive Principles, Amerika Serikat: Componies.

Kemendiknas. 2010. Desains Induk Pendidikan Karakter, Jakarta: Kemendiknas.

Kesuma, Dharma, dkk. 2011. Pendidikan Karakter Kajian Teori dan Praktek di Sekolah, Bandung: PT Remaja Rosdakarya.

Lickona, Thomas. 1991. Educations for Character: How Our School Can Teach Respect and Responsibility, New York: Bantam Books.

Majid, Abdul, dan Dian Andayani. 2012. Pendidikan Karakter Perspektif Islam, Bandung: Rosda Karya.

Megawangi, Ratna. 2004. Pendidikan Karakter Solusi yang Tepat untuk Membangun Bangsa, t.tpen: BPMIGAS dan Star Energy.

Mu'in, Fathul. 2011. Pendidikan Karakter Kontribusi Teoritik dan Praktik, cet.II, Yogyakarta: ArRuzz Media. 
Nawawi, Imam. 2011. Riyadus Shalihin, diterjemahkan oleh Arif Rahman Hakim, Solo: Insan Kamil.

Rauf, Rusdin S. 2008. Smart Heart, Yogyakarta: Diva Press.

Republik Indonesia. 2007. Undangundang Republik Indonesia Nomor. 17 Tahun. 2007, Tentang Rencana Pembangunan Jangka Panjang 2005-2025, Jakarta: Sekretariat Negara.

Republik Indonesia. 2010. Kebijakan Nasional Pembangunan Karakter Bangsa, Jakarta: Kemko Kesejahteraan Rakyat.

Sudrajat, Ajat. 2010. "Pengembangan Soft Skill Mahasiswa UNY yang Berkarakter, Makalah Seminar Tutorial PAI UNY, 20 Oktober.

Suparlan. 2010. Pendidikan Karakter: Sedemikian Pentingkah dan Apa yang Harus Dilakukan, www.suparlan.com, unduh, 10 Desember.

Winataputra, Udin Sarifudin. 2010. Implementasi kebijakan Nasional Pembangunan Karakter Bangsa Melalui Pendidikan Karakter. Geoglel.com. unduh, tanggal 5 Desember.

Zuhdi, $\quad$ Darmiyati. 2010. Pengembangan Model Pendidikan Karakter Terintegrasi Dalam Pembelajaran Bidang Studi Di Sekolah Dasar, Yogyakarta: LEMLIT UNY. 


\section{UCAPAN TERIMA KASIH}

Redaksi Jurnal Humanika mengucapkan terima kasih atas partisipasi dan kesediaan Mitra Bestari untuk Volume. 15. Nomor. 1. September 2015, kepada;

Ajat Sudrajat (Universitas Negeri Yogyakarta) untuk artikel

1. "Islam Rahmah dan Wasathiyah (Paradigma Keberislaman Inklusif, Toleran dan Damai)" (Abd. Malik Usman)

2. "Etika Sosial dalam Kerukunan Umat Beragama (Studi Kasus di Desa Kotesan Kecamatan Prambanan Kabupaten Klaten Jawa Tengah)” (Andy Dermawan dan Zunly Nadia)

3. "Mencari Model Pendidikan Karakter" (Suparlan)

Suranto Aw (Universitas Negeri Yogyakarta) untuk artikel

1. "Persepsi Masyarakat Kotagede terhadap Pengunaan Media Komunikasi oleh Organisasi Forum Joglo untuk Pelestarian Budaya di Kotagede Yogyakarta” (Choirul Fajri)

2. "Implikasi Budaya Organisasi terhadap Pola Perilaku Komunikasi Kelompok Tani Sumber Rejeki” (Mariana Ulfah dan Siti Chotijah)

3. "Model Komunikasi "Wom” sebagai Strategi Pemasaran Efektif” (Dani Fadillah)

Yayan Suryana (Universitas Islam Negeri Sunan Kalijaga Yogyakarta) untuk artikel

1. "The Dialectics of Javanese and Islamic Cultures: an Introduction to Kuntowijoyo’s Thought” (Pradana Boy ZTF) 